\title{
Els estudis sobre el moviment veïnal: un repte encara per a la historiografia
}

\section{IVAN BORDETAS}

Historiador

És un fet objectiu que en els darrers anys l'estudi dels moviments socials ha guanyat terreny en el camp de la historiografia sobre el franquisme. Però també ho és que aquest s'ha produït sobre camins ja transitats com és el de la història del moviment obrer. Resulta també un altre fet innegable, tot i les recerques recents, que altres moviments socials que batallaren contra el franquisme han tingut molta menys ascendència entre vells i nous investigadors. Però en aquesta relació, si el moviment estudiantil compta amb interessants novetats en la recerca i es pot considerar convenientment inserit en les monografies sobre l'època, el moviment veïnal continua essent el fill pobre dels moviments socials durant la dictadura. ${ }^{1}$

\section{Transició, canvi polític: sobre els protagonismes}

El moviment veïnal continua apareixent, en la majoria de casos, com la comparsa d'obligada referència en la llarga enumeració dels actors socials que participaren de l'antifranquisme. Però poc més, perquè, de fet, encara no podem parlar d'una correcta inserció de les noves investigacions en els relats sobre el franquisme i l'antifranquisme i, en darrera instància, sobre el procés de transició. Quan se li dóna cert protagonisme, aquest sol aparèixer seguint vells esquemes que el situen en el camp de l'aprenentatge de la llibertat, fixant la seva actuació en el temps curt del canvi polític, subordinat als agents polítics i socials rellevants - partits i sindicats-, i plantejant relats edulcorats i reduccionistes sobre el seu paper.

De fet, és lògic que així sigui en la mesura que una part de la historiografia sobre aquest temps històric continua dominada per interpretaci-

1 M. Ortiz, «Movimientos sociales y sociabilidad en Castilla-La Mancha durante el segundo franquismo", dins A. Mateos \& A. Herrerín, ed., La España del presente: de la dictadura a la democracia. II Congreso Internacional de la Asociación de Historiadores del Presente (Torrescaballeros: Asociación de Historiadores del Presente, 2006): 322. 
ons que neguen o minimitzen el protagonisme social, la conflictivitat i l'oposició antifranquista i fixen dos grans paradigmes explicatius. ${ }^{2}$ Uns atorguen a les elits polítiques - des del rei fins als denominats reformistes del règim i, des d'una altra perspectiva, però que és complementària, als líders de l'oposició- el protagonisme en la fi de la dictadura. ${ }^{3}$ Uns altres, des d'un punt de vista purament mecànic, atribueixen el canvi polític al procés de modernització i els canvis estructurals associats al desarrollismo. ${ }^{4}$ Encara altres estudis que són complementaris a aquestes visions incideixen en presumptes desmobilitzacions i en la passivitat social o en la influència de cultures polítiques basades en la moderació i el consens que redueixen els actors socials a simples espectadors del procés. ${ }^{5}$ Només a la llum d'un altre corrent historiogràfic, aquell que situa la conflictivitat social i política en el centre del debat, s'ha pogut i es pot desenvolupar la recerca sobre els moviments socials i, particularment, veïnals. Aquest corrent interpreta la mobilització sociopolítica antifranquista com el factor principal, sinó necessari, de la crisi de la dictadura i la seva posterior liquidació institucional. ${ }^{6}$

\section{Moviment veïnal, antifranquisme, lluita de classes i canvi polític}

El moviment veïnal, en consonància amb la seva potencialitat, va ser objecte d'un considerable interès en el mateix moment de la seva màxima ac-

2 Un parell de treballs que minimitzen l'acció collectiva: Álvaro Soтo, ¿Atado y bien atado? Ins titucionalización y crisis del franquismo (Madrid: Biblioteca Nueva, 2005) i M. REDERO, «Apuntes para una interpretación de la transición política en España», Ayer 36 (1999): 261-282.

3 C. SECO, «La Corona en la transición española», dins J. Tusell \& A. Soto, ed., Historia de la Transición, 1975-1986 (Madrid: Alianza, 1996), 138-158, i C.T. PowelL, El piloto del cambio. El Rey, la monarquía y la transición a la democracia (Barcelona: Planeta, 1991).

4 Per exemple J.F. Tezanos, «La crisis del franquismo y la transición democrática», dins J.F. Tezanos, R. Cotarelo \& A. DE Blas, ed., La transición democrática española (Madrid: Sistema, 1989), 9-28.

5 V. PÉREZ, La primacía de la sociedad civil. El proceso de formación de la España democrática (Madrid: Alianza, 1993) i R. Fishman, Organización obrera y retorno a la democracia en España (Madrid: Siglo XXI/CIS, 1990). També C. SASTRE, Transición y desmovilización política en España (19751978) (Valladolid: Universidad de Valladolid, 1997).

6 No ens podem aturar aquí en una ressenya crítica sobre aquestes investigacions. Vegeu l'estat de la qüestió recent publicat en aquesta mateixa revista: P. YsÀs, «Ni modèlica ni immodèlica. La transició des de la historiografia», Franquisme \& Transició 1 (2013): 273-308. http://journals.uoc. edu/index.php/franquismeitransicio. 
tivitat durant la dècada dels setanta. La gran majoria d'estudis posteriors beuen, en bona mesura, d'aquestes primeres aproximacions que es van fer a l'òrbita del pensament marxista. Manuel Castells i Jordi Borja representaren dos dels principals i més influents teòrics sobre el moviment veïnal a l'Estat espanyol. Les seves propostes interpretatives es presenten hereves de contribucions de pensadors que plantejaren, com féu Henri Lefebvre, una nova visió sobre una sociologia urbana que fins al moment no s'havia ocupat de la conflictivitat social que es produïa a les ciutats i que proposava la definició d'allò urbà per la seva naturalesa espacial però també com a àmbit i objecte d'estratègies polítiques i d'interessos econòmics.?

Manuel Castells, partint d'una òptica analítica althusseriana, va plantejar una anàlisi de la problemàtica urbana i els processos de canvi social, atesos sobretot els moviments socials urbans, amb relació a la crisi del capitalisme avançat de la postguerra mundial. La problemàtica urbana era indissociable del fenomen de la lluita de classes que, a les ciutats, s'expressava partint d'una triple crisi: una crisi econòmica estructural, producte de la contradicció entre les necessitats d'acumulació de capital, la concentració de força de treball i les necessitats de reproduir-la a partir dels mitjans de consum collectiu; una crisi urbana caracteritzada per la incapacitat d'assegurar la producció, distribució i gestió dels mitjans de consum collectiu, i, per últim, una crisi de l'estat que, subsidiàriament, havia de garantir tant l'acumulació de capital com la reproducció de la força de treball produint i mantenint un equipament collectiu constantment deficitari respecte a les necessitats expressades per la població. ${ }^{8}$ Ricard Martínez, recollint les aportacions de Castells, mostra els límits d'aquests plantejaments, «derivats en bona part de la seva forta empremta althusseriana: un excés teoricista, un fort reduccionisme que el porta a ignorar els aspectes culturals del fet urbà i una concepció restrictiva dels moviments socials urbans». ${ }^{9}$

7 H. Lefevbre, La revolución urbana (Madrid: Alianza, 1972) i El derecho a la ciudad (Barcelona: Península, 1978).

8 M. Castells, La cuestión urbana (Madrid: Siglo XXI, 1974); Movimientos sociales urbanos (Madrid: Siglo xxI, 1977) i Ciudad, democracia y socialismo (Madrid: Siglo xxI, 1977).

9 R.MARTÍNEZ, El moviment veïnal a l'àrea metropolitana de Barcelona durant el tardofranquisme i la transició: el cas de Sabadell (1966-1976) (tesina de doctorat, Universitat Pompeu Fabra, 1999), 11. 
Jordi Borja, coincidint amb Castells, va accentuar la necessitat d'estudiar els moviments en relació amb les contradiccions del desenvolupament urbà, atenent també a les qüestions culturals i identitàries i considerant les organitzacions veïnals com a elements de cohesió social als barris..$^{10}$ Marçal Tarragó, introduiria matisos importants en considerar que l'acció del moviment presentava una gran varietat d'objectius —des dels estrictament reivindicatius dels dèficits fins als polítics relacionats amb la representativitat, gestió o participació institucional. També situant el context específic de la dictadura franquista, considerava que l'acció veïnal adquiria un caràcter polític natural, tant per la resposta del règim com per la seva incidència, que situava en el mateix nivell que el moviment obrer i el polític. ${ }^{11}$

Quant a l'estudi del moviment veïnal barceloní, una de les primeres aportacions es deu a José Olives, que, també des d'una perspectiva marxista, es va apropar als factors que van permetre l'eclosió de la protesta urbana, les formes organitzatives adoptades, els efectes urbans i polítics de la seva actuació i, per últim, els seus objectius i plantejaments. Destaca de la seva anàlisi la fixació de l'origen de la protesta en els barris obrers. Fixant un altre element que seria motiu de debat en posteriors recerques, també considerava que la mobilització urbana no tenia un caràcter espontani sinó que responia a la forta influència que havien tingut els partits i grups polítics en la seva eclosió. ${ }^{12}$

Entre 1975 i 1978 es va produir una extensíssima producció teòrica sobre els moviments socials urbans a l'Estat espanyol que responia, de fet, al context polític. Companys de viatge del moviment veïnal, aquests autors s'afanyaren a participar del conflicte amb obres que no representen investigacions acadèmiques sinó més aviat eines de combat ideològic que, si d'una banda ofereixen una bona radiografia del moviment veïnal, reflectien, en moltes ocasiones, les propostes polítiques que defensaven.

10 J. BORJA, «Elementos teóricos para el análisis de los movimientos reivindicativos urbanos», Cuadernos de Arquitectura y Urbanismo 94 (1973): 57-61; «Movimientos urbanos de las clases populares: movimiento reivindicativo, movimiento democrático, dualidad de poder», Papers. Revista de Sociologia 3 (1974): 39-61, i Movimientos sociales urbanos (Buenos Aires: Ediciones SIAP, 1975).

11 M. Tar ragó, Política urbana y luchas sociales (Barcelona: Avance, 1976).

12 J. OlIVÉs, El movimiento social urbano. Barcelona 1969-1972 (tesi doctoral, Universitat de Barcelona, 1973) i «La conflictualidad urbana», Papers. Revista de Sociologia 3 (1974): 275-323. 
Eren obres, com també les de Borja i Castells, profundament ideologitzades que volien incidir en la pugna antifranquista i en el debat sobre un futur que quasi es tocava. ${ }^{13}$ Un darrer grup d'obres que es produïren en aquest moment afegiren una qüestió cabdal que encara està per esclarir. Tot i assenyalar-nel'extensió geogràfica, la potencialitat de les propostes o la radicalitat de les lluites, es constatava el moment d'impasse en què semblava haver-se installat, i els límits i condicionants que se li estaven imposant a partir del procés d'institucionalització política que es produïa des de $1977 \cdot{ }^{14}$ Aquestes obres posen l'investigador sobre la pista d'unes línies de crisi del moviment que trenquen amb el consens acadèmic que es va installar després, referit a l'aparició d'aquestes fractures només a partir de l'elecció i l'actuació dels ajuntaments democràtics escollits el 1979; de la mateixa manera que també l'informen sobre determinades actuacions i conseqüències del model de transició que finalment es va imposar.

\section{El veïnal, nou o vell moviment social?}

Durant els vuitanta es van iniciar les que podríem considerar obres acadèmiques sobre el moviment veïnal, amb dos treballs quasi simultanis sobre la capital catalana: l'un, de Josep Martí, que, tot i limitar la idea d'expressió política a la presència de militants de partit i obviar-ne altres aspectes informals, es dedicava a la interrelació d'organitzacions veïnals i partits polítics, i destacava la fortíssima presència de l'esquerra antifranquista; ${ }^{15}$ l'altre, d'Anna Alabart, és una obra de conjunt sobre

13 És impossible fer aquí una anàlisi detallada d'aquestes obres. Només com a exemple, en llistarem algunes: J.M. AlibÉs, F. Miguélez, M.J. Pardo et al., «La lucha de los barrios de Barcelona 1969-75", CAU 34 (nov.-des. 1975): 26-117; T.R. VILlasante, Los vecinos en la calle. Por una alternativa democrática a la ciudad de los monopolios (Madrid: Ediciones de la Torre, 1976); CIDUR, Madrid/ Barrios 1975 (Madrid: Ediciones de la Torre, 1976); J. Mayoral, D. Antona, A. Villanueva et al., Vallecas: las razones de una lucha popular (Madrid: Mañana, 1976); EQuipos DE Estudio, La lucha de barrios en Barcelona (Barcelona: Elías Querejeta Ediciones, 1976); J. García \& M.D. GonZÁLEZ, Presente y futuro de las Asociaciones de Vecinos (Madrid: Pecosa, 1976).

14 J. OMEÑACA, Movimiento ciudadano: crisis (Bilbao: Ellacuría, 1977); AAVV, Las Asociaciones de Vecinos en la encrucijada. El movimiento ciudadano en 1976-77 (Madrid: Ediciones de la Torre, 1977) i J. Angulo, Municipio, elecciones y vecinos. Por unos ayuntamientos democráticos (Madrid: Ediciones de la Torre, 1978).

15 J. MARTí, Relació entre Associacions de Veïns i partits polítics. Barcelona 1970-1980 (tesina de doctorat, Escola de Ciències Socials de l'ICESB, 1981). 
l'evolució urbanística, la segregació social de la ciutat i la inserció del moviment en aquesta dinàmica urbana. ${ }^{16}$ Poc després, Manuel Castells tornaria a irrompre en l'estudi del moviment veïnal amb un extens apartat dedicat a Madrid inclòs en la seva darrera monografia dedicada als moviments socials urbans, on s'allunyava definitivament d'anteriors rigideses analítiques i se centrava en els subjectes protagonistes de la mobilització - entre els quals, les dones-, en la dimensió cultural del moviment pel que fa a l'enfortiment de xarxes socials i a la creació de llaços comunitaris als barris, i en l'impacte de l'acció veïnal en la configuració urbana és, en definitiva, la concepció del moviment veïnal com a productor de ciutat. Val a dir que, això no obstant, l'estudi tendeix a sobredimensionar el caràcter interclassista de la protesta. ${ }^{17}$ Víctor Urrutia, per la seva banda, és autor de l'única síntesi de conjunt sobre el moviment veïnal a Bilbao, la qual a més destaca per demostrar el paper fonamental que aquest moviment va tenir en el procés de deslegitimació de la dictadura i a l'hora de forçar-ne el canvi polític. ${ }^{18}$ Tomás R. Villasante també contribuiria en aquesta producció bibliogràfica amb l'estudi dels factors i actors que participaren en l'origen i en l'evolució del moviment veïnal: catòlics de base, militants marxistes i veïns afectats per la crisi urbanística producte de la desídia de postguerra i de la política urbanística agressiva i especulativa posterior. ${ }^{19}$

Encara dels anys vuitanta, cal fer esment en darrer lloc a l'obra d'Alice Gail Bier, que va iniciar una línia d'anàlisi, amb cert recorregut en obres posteriors, segons la qual certs fenòmens exògens suposen la clau explicativa fonamental de l'origen del moviment veïnal: en aquest cas, la promulgació de la Llei d'Associacions de 1964, que entén com una mena de revulsiu que activaria la protesta. Bier fa una assimilació reduccionista entre moviment veïnal i associacions de veïns que esdevé un problema metodològic encara més greu en la mesura que les considera només des

16 A. Alabart, Els barris de Barcelona i el moviment associatiu veïnal (tesi doctoral, Universitat de Barcelona, 1981).

17 M. CASTElls, La ciudad y las masas. Sociología de los movimientos sociales urbanos (Madrid: Alianza, 1983).

18 V. UrRutia, El movimiento vecinal en el área metropolitana de Bilbao (Oñati: Instituto Vasco de Administración Pública, 1985).

19 T.R. Villasante, Comunidades locales: análisis, movimientos sociales y alternativas (Madrid: IEAL, 1984). 
que són legals i que la duu per tot plegat a afirmar que seria només a partir de la mort del dictador - un altre factor exogen - quan es podria parlar d'una activitat efectiva d'aquestes associacions, gran part de les quals es van legalitzar en aquesta nova etapa. ${ }^{20}$

Estudis posteriors se situen ja en consonància amb la bibliografia general sobre els moviments socials que, principalment des de la sociologia o les ciències polítiques, han reflexionat sobre les formes d'acció i d'organització, els objectius, els factors i els actors que intervenen en la seva aparició, organització o condicionants. ${ }^{21}$ Aquests estudis també s'han vist fortament influïts pels diferents models teòrics sobre els anomenats nous moviments socials — entre els quals alguns autors situen el veïnalque no s'explicarien des del paradigma de la lluita de classes perquè els seus integrants no es definirien per la classe, perquè les seves reivindicacions no serien exclusivament econòmiques i perquè utilitzarien noves formes organitzatives i estratègies de mobilització que els allunyarien del vell moviment per excellència, que seria l'obrer. ${ }^{22}$

Ja als anys noranta sortiren a la llum dues noves visions de conjunt sobre el moviment a Barcelona. La primera planteja el relat de l'evolució del moviment des dels seus orígens fins als anys noranta a partir de l'anàlisi d'un bon nombre de conflictes que tracen a la perfecció el recorregut des d'unes primeres lluites contra determinats dèficits o plans parcials agressius fins al plantejament d'alternatives globals de ciutat. ${ }^{23}$ La segona se centra en la incidència del moviment en la conformació física i cultural de la ciutat. Segons els autors, el moviment veïnal no desenvoluparia mai una idea global de ciutat, qüestió perfectament refutada en posteriors investigacions. De la mateixa manera, s'explicava l'evolució de la protesta

20 A.G. BIER, Crecimiento urbano y participación vecinal (Madrid: CSIC, 1980).

21 Per exemple, el recent I. AHEDo, «Acción colectiva vecinal en el tardofranquismo: el caso de Rekalde», Historia y Política 23 (2010): 275-296.

22 Vegeu, per exemple, J.Álvarez, «Movimientos sociales en España: del modelo tradicional a la modernidad posfranquista», dins E. LARAÑa \& J. GuSFIELD, ed., Los nuevos movimientos sociales. De la ideología a la identidad (Madrid: CIS, 1994), i E. LARAÑA, La construcción de los movimientos sociales (Madrid: Alianza, 1999).

23 J.M. Huertas \& M. Andreu, Barcelona en lluita. El moviment urbà 1965-1996 (Barcelona: FAVB, 1996). 
sense atendre'n els aspectes socials i culturals o la dinàmica pròpia, sinó a partir de la successió de les diferents administracions locals. ${ }^{24}$

Estudis posteriors han reforçat les aportacions fetes fins llavors sobre el moviment veïnal a partir de perspectives diferents i complementàries. Si ja alguns treballs sobre el moviment obrer tractaven tangencialment la qüestió urbana i la mobilització veïnal, ${ }^{25}$ els darrers estudis dedicats a l'església, en particular als moviments apostòlics obrers, han illuminat un aspecte clau de la configuració del moviment veïnal: el paper d'aquests actors en la construcció dels primers discursos crítics sobre la situació al barri i la importància de la xarxa de recursos materials que es posaren al servei de l'organització i mobilització veïnals. ${ }^{26}$

Al treball pioner de García-Nieto, que utilitzava les fonts orals per a l'estudi del moviment, l'han seguit diferents aportacions, totes centrades en espais concrets que han permès corroborar i completar les hipòtesis en què es basava aquell primer estudi; això és, la importància per a l'activació de la lluita de les xarxes socials teixides als barris, de la conformació d'identitats collectives amb una particular significació de l'obrera, del paper del conflicte i del temps de lluita en l'articulació de les solidaritats, i de la importància de determinats actors, des d'aquestes xarxes veïnals fins als catòlics de base passant pels militants de partits polítics. ${ }^{27}$ També entre el cúmul d'històries locals del període franquista podem trobar

24 M. Domingo \& M.R. Bonet, Barcelona i els moviments socials urbans (Barcelona: Mediterrània, 1998).

25 Des del clàssic S. BALfour, La dictadura, los trabajadores y la ciudad. El movimiento obrero en el área metropolitana de Barcelona, 1939-1988 (València: Alfons el Magnànim, 1994) fins als més recents J.A. PÉREZ, Los años del acero. La transformación del mundo laboral en el área industrial del Gran Bilbao (1958-1977). Trabajadores, convenios y conflictos (Madrid: Biblioteca Nueva, 2001). Són particularment interessants els estudis de X. Domènech, Quan el carrer va deixar de ser seu. Movi ment obrer, societat civil i canvi polític. Sabadell (1966-1976) (Barcelona: Publicacions de l'Abadia de Montserrat, 2000) i Cambio político y movimiento obrero bajo el franquismo. Lucha de clases, dicta dura y democracia (1939-1977) (Madrid: Icaria, 2012).

26 E. Ferrando, Cristians i rebels. Història de l'HOAC a Catalunya durant el franquisme (19461975) (Barcelona: Mediterrània, 200o), F. MARTínez, La JOC a Catalunya. Els senyals d'una Església del demà (1947-1975) (Barcelona: Mediterrània, 2000) i J. FeRnÁNDEZ, La participación de los católicos en el movimiento obrero de Barcelona (1946-1978) (tesi doctoral, Universitat de Barcelona, 2005).

27 M.C. García-Nieto, «Marginalidad, movimientos sociales, oposición al franquismo. Palomeras, un barrio obrero de Madrid, 1950-1980", dins J. Tusell, A. Alted \& A. MATEOS, coord., La oposición al régimen de Franco, II (Madrid: UNED, 1991), 269-285. 
algunes obres que tracten el moviment veïnal amb una sàvia combinació entre fonts orals i documentals. Són, en aquest sentit, paradigmàtics els estudis d'Angelina Puig i Josep Lligadas. ${ }^{28} \mathrm{Si}$ el primer resulta clau per comprendre políticament les primeres migracions de postguerra i com aquest fenomen impacta en la creació de xarxes socials als barris, el segon ens illustra sobre la importància d'aquestes xarxes en l'activació de la protesta urbana. Tancant el capítol d'aquelles obres que es basen, fonamentalment, en la memòria oral, destaquen les aportacions de Xavier Domènech pel cas català i d'una obra collectiva dedicada a Bilbao. ${ }^{29}$ Si el primer ressalta el paper de les xarxes socials i els elements que operen en la construcció identitària dels protagonistes de la protesta — des dels processos d'autoreconeixement i de creació de subjectes collectius fins als discursos que legitimarien l'acció collectiva passant per la interrelació amb altres identitats com l'obrera-, els segons plantegen una anàlisi comparada sobre la manera com s'articulen unes identitats molt fortes als barris de Deusto i Rekalde. D’aquest darrer estudi en destaca, sobretot, la importància que s'atorga als espais de sociabilitat o a l'experiència del conflicte urbà. Altres obres que se centren en la interrelació entre el món obrer i l'urbà a escala local també ofereixen pistes per entendre com els veïns que viuen experiències similars acaben generant unes xarxes socials que són les que fan emergir i sostenir després el conflicte. ${ }^{30}$

28 A. Puig, Naixement i creixement dels barris perifèrics a les ciutats industrials de Catalunya. His tòria viva de Torre Romeu, Sabadell (tesina de doctorat, Universitat Autònoma de Barcelona, 1989) i De Pedro Martínez a Sabadell: l'emigració, una realitat no exclusivament econòmica. 1920-1975 (tesi doctoral, Universitat Autònoma de Barcelona, 1990); J. Lligadas, Cerdanyola, el barri gran Mataró, 1920-200o. Construir la vida des de la immigració dels anys 50 (Mataró: Patronat Municipal de Cultura, 2000).

29 X. DomÈnech, «La reconstrucció de la raó democràtica. Del suburbi a la ciutat», dins C. MoLINERo \& P. YsÀs, coord., Construint la ciutat democràtica. El moviment veïnal durant el tardofranquisme i la transició (Barcelona/Bellaterra: Icària/UAB/Memorial Democràtic, 2010), 113-155; íd., «Orígenes. En la protohistoria del movimiento vecinal bajo el franquismo», Historia del Presente 16 (2010): 27-41, i Grupo de investigación Parte Hartuz, Deusto y Rekalde. Historia e identidad contada por sus protagonistas (Bilbao: Ayuntamiento de Bilbao, 2008).

3o Per exemple, J. Hernández, El Cerro del Águila e Hytasa. Culturas del trabajo, sociabilidad e imágenes de identificación (Sevilla: Diputación de Sevilla, 1999); J.A. PÉrEZ, «El espacio urbano y el movimiento obrero en el área del Gran Bilbao a lo largo del desarrollismo franquista», i A. GómEZ, "Cómo queríamos vivir. Astilleros y Malvarrosa en la Valencia de los primeros 1970", dins J. TÉBAR, ed., El movimiento obrero en la gran ciudad. De la movilización sociopolítica a la crisis económica (Barcelona: El Viejo Topo, 2011), 117-146 i 219-241. 
Una de les interpretacions més completes sobre moviment veïnal en l'àmbit local la va presentar Ricard Martínez referida a la ciutat de Sabadell. ${ }^{31}$ Entre les principals aportacions destaca la reintroducció de la perspectiva de classe en l'estudi del moviment a partir de l'anàlisi de les formes i valors que n'articularen la identitat: el barri com a espai d'experiències homogènies — vida quotidiana i conflicte-, l'origen immigrant dels veïns mobilitzats i la condició obrera de la gran majoria d'ells. Es tracta, doncs, d'un estudi realment inspirador, que s'apropa al moviment veïnal en «termes d'autoorganització i exercici directe de democràcia per part de les classes subalternes», que s'expressen en la lluita per l'associació, l'expressió i l'organització autònomes, la substitució pràctica del poder públic i la funció de contrapoder pel seu impacte en la configuració urbana, per les seves propostes alternatives al model de ciutat i de gestió municipal, i per la seva tasca de deslegitimació de les autoritats franquistes. Tots aquests elements permeten a l'autor fixar el paper cabdal que va tenir el moviment veïnal en el procés de canvi polític. De la mateixa manera, l'autor s'atura en la dimensió anticapitalista del moviment veïnal i analitza les pràctiques i els discursos basats en l'existència d'un deute social envers els veïns, la identificació dels adversaris en termes de classe, la crítica al capitalisme en general i urbà en particular i, per últim, l'edificació de models de ciutat alternatius. ${ }^{32}$ Martínez, però, mostra un recorregut que pot pecar d'excessiva linealitat i reduccionisme en la mesura que estableix les diferents etapes que recorreria el moviment veïnal com un continuum que comença en una activitat assistencial i de gestió, passa per fer peticions a les autoritats i acaba en un moviment ja més reivindicatiu i marcat pel conflicte. Altres investigacions han matisat aquesta visió analitzant les primeres pràctiques des de la lògica de l'autogestió i de l'autoorganització i com a base per a l'empoderament popular; unes pràctiques, doncs, que mai no s'abandonarien i que no es transformarien simplement en peticions. De la matei-

31 R. MARTínez, El moviment veïnal a l'àrea metropolitana. Vegeu també «El moviment veïnal a Sabadell durant el tardofranquisme, 1966-1976: "Todos los barrios unidos para conseguir sus derechos"», I i II, Arraona 24 i 25 (primavera i tardor 2001): 65-87 i 75-97.

32 S'incideix en aquest aspecte a R. MARTÍNEZ, «Construir futurs. La dimensió anticapitalista del moviment veïnal», dins Molinero \& Ysàs, Construint la ciutat democràtica, 265-317. També a «Movimiento vecinal, antifranquismo y anticapitalismo», Historia, Trabajo y Sociedad 2 (2011): 63-9o. 
xa manera, el temps del conflicte no es presenta tan allunyat dels passos inicials com tampoc no es donà sempre que existia una organització formal.

En els darrers anys s'ha produït un gran avenç en els estudis sobre el moviment veïnal, gràcies als quals s'han anat omplint espais geogràfics orfes de recerques i guanyant noves complexitats d'anàlisi. Al final de la dècada passada es van publicar dues obres de conjunt sobre els casos madrileny i barceloní. La primera, estructurada en tres parts - identitat veinal, testimonis sobre la mobilització, present i futur del moviment-, intentava recollir tant les noves interpretacions sobre el paper de les dones i la qüestió de gènere en la protesta de barris o les visions antropològiques sobre la construcció d'identitats, com la revisitació de clàssics sobre el moviment veïnal o la conjugació entre obrers i veïns a la perifèria madrilenya. ${ }^{33}$ Aquest volum es complementa amb un text anterior sobre la interrelació entre la producció franquista de la ciutat i la mobilització veïnal atenent a una cronologia àmplia que refusava centrar-se només en els anys de la transició. ${ }^{34}$ El contrapunt català estaria representat, de fet, per un conjunt variat d'obres. Una, d'Albert Recio y Andrés Naya, proposava reflexions crítiques respecte a la relació entre partits i moviment — sobre la visió instrumental dels dirigents dels primers-, a més de destacar la importantíssima aportació de la protesta urbana en el procés de canvi polític. ${ }^{35}$ La segona obra, un volum collectiu, plantejava un recorregut per les principals lluites i reivindicacions del moviment veïnal barceloní, les quals permetrien confirmar novament el paper d'aquest darrer com a productor de l'espai urbà. Aquest llibre feia dues aportacions més: incidia en el sentit anticapitalista d'aquestes protestes i s'aturava a estudiar-ne la participació femenina. En aquest darrer sentit, doncs, si d'una banda reforçava la dimensió anticapitalista que ja va indicar Martínez,

33 V. Pérez \& P. SánChez, ed., Memoria ciudadana y movimiento vecinal. Madrid: 1968-20o8 (Madrid: Los Libros de la Catarata, 2008).

34 P. CARmona \& E. Rodríguez, «Barrios: planificación, inmigración y movimiento vecinal (1939-1986)", dins ObSERVATOR Io Metropolitano, Madrid: ¿la suma de todos? Globalización, territorio, desigualdad (Madrid: Traficantes de Sueños, 2007), 333-389.

35 A. Recio \& A. NAYA, "Movimiento vecinal: Claroscuros de una lucha necesaria», Mientras Tanto, 91-92 (2004): 63-81. 
de l'altra, és un exemple de com les qüestions de gènere comencen a integrar-se en els estudis sobre el moviment veïnal. ${ }^{36}$

Al principi de la dècada actual van veure la llum dues aportacions de la historiografia catalana compromesa amb la història social del període. La primera és un volum collectiu que recollia textos de Domènech i Martínez ja citats, a més d'un d'Iván Bordetas i un altre d'aquest mateix en collaboració amb Anna Sánchez. El primer de Bordetas reivindica la necessitat d'estudiar la configuració suburbial i les polítiques urbanístiques i la inserció de l'espai en l'anàlisi de l'emergència de la protesta i la formació de l'univers cultural veïnal. El signat amb Sánchez traça, en canvi, les principals línies interpretatives del període de màxima fortalesa, mobilització i incidència del moviment català en el seu conjunt; insisteix en la seva importància cabdal en el procés de transició, ${ }^{37}$ i analitza també els primers símptomes de crisi del moviment veïnal durant la conjuntura 1977-1979, una hipòtesi que s'associa al procés d'institucionalització i pèrdua de protagonisme de l'antifranquisme social respecte a l'antifranquisme polític. La segona aportació d'aquesta dècada actual és un monogràfic de la revista Historia del Presente amb textos de Domènech — ja citat-, de Bordetas, que planteja una perspectiva sobre el moviment veïnal als principals centres urbans de l'Estat espanyol - Madrid, Bilbao i Barcelona - a partir de la recerca doctoral en aquell moment en curs i, per últim, de Claudia Cabrero sobre la participació femenina..$^{8}$

Aquesta darrera línia d'investigació, la del paper de les dones i la qüestió de gènere en el moviment veïnal, representa una de les principals aportacions de les noves recerques sobre un aspecte cabdal i absolutament oblidat. Cabrero, a partir del cas asturià, es dedica a l'estudi d'aquesta participació femenina a la protesta urbana i ha indicat que la consciència social i política entre les dones no es genera només en moviments polítics i sindicals organitzats, sinó també a partir d'una consciència

36 1970-2010, 40 anys d'acció veïnal (Barcelona: Mediterrània, 2010). Les aportacions citades, respectivament: Albert Recio, «Anticapitalisme a peu de carrer» i Eva Fernández, «Quan les dones van conquerir mig cel».

37 Molinero \& Ysìs, Construint la ciutat democràtica.

$38 \mathrm{X}$. DOMÈNECH, «Orígenes. En la protohistoria del movimiento vecinal bajo el franquismo» i I. BORDETAS, «El movimiento vecinal en el tránsito de la resistencia a la construcción de alternativas», Historia del Presente 16 (2010): 27-41 i 43-61. 
femenina basada en la solidaritat, la defensa del seu rol social, la sociabilitat o les tradicions culturals, que operen en la seva actuació veïnal. ${ }^{39}$ L'autora també considera el difícil encaix que van tenir les qüestions i la identitat de gènere tant en el moviment veïnal com en l'antifranquisme en general, i ha mostrat com, ni en un espai ni en l'altre, aquest debat no es va afrontar amb la plena integració de la dona i de la seva problemàtica específica en els discursos projectats cap al canvi polític. Un estudi recent sobre les vocalies de dones a les Associacions de Veïns de Barcelona ha complementat i ampliat la recerca. ${ }^{40}$ Analitza com sorgeixen i s'estenen les seves pràctiques, discursos i projectes, i les relacions ambivalents que es van establir, d'una banda, amb el moviment veïnal — per fer-ho, parteix, en aquest cas, de la invisibilitat femenina en l'estructura organitzativa del moviment veïnal, però no en la protesta de carrer, i de com els activistes recelaven que fossin idonis els espais que no eren mixtes o els projectes construïts en clau de diferència- i, de l'altra, amb el feminista - se centra, en aquest darrer aspecte, en el debat sobre l'autenticitat feminista d'aquestes formes organitzatives i de la inclusió en la seva agenda reivindicativa d'aquelles qüestions que es refereixen al consum collectiu o a les tasques derivades de la reproducció. L'autora conclou que les vocalies van tenir una agenda compartida amb el feminisme i van representar, de fet, un altre dels corrents dels feminismes.

Una investigació recent, que no integra les darreres aportacions historiogràfiques sobre la qüestió, és la de Pamela Radcliff, que es proposa estudiar tant les associacions familiars del Movimiento - Amas de Casa, Cabezas de Familia y Padres de Familia- com les associacions de veïns..$^{41}$ Si és interessant considerar aquestes associacions del règim, alguna de les quals fou utilitzada per a la protesta urbana antifranquista, resulta, en canvi, problemàtic situar-les en un mateix pla d'anàlisi, de manera que es pot afirmar que compartien objectius i un «common interest in legitimating greater popular participation in public affairs». Radcliff proposa un

39 C. CABRERo, «Género, antifranquismo y ciudadanía. Mujeres y movimiento vecinal en la Asturias del desarrollismo y el tardofranquismo», Historia del Presente 16 (2010): 9-26.

40 E. Fernández, Vocalies de dones de Barcelona a la Transició Democràtica: una experiència emancipadora (tesina de doctorat, Universitat Autònoma de Barcelona, 2009).

41 P. RADCLIFF, Making democratic citizens in Spain. Civil society and the popular origins of the transition, 1960-1978 (Nova York: Palgrave MacMillan, 2011). 
model explicatiu de la gènesi del moviment a partir d'una barreja eclèctica d'elements: la política franquista - es refereix, sense més consideracions, a un nou llenguatge de participació i de liberalització, i a una pretesa relaxació de la repressió-; els canvis estructurals i el capital social, i els recursos culturals que aportarien militants antifranquistes i catòlics de base. Els veïns, en aquest esquema, apareixen com una categoria d'anàlisi passiva, al marge, purament receptora d'estímuls externs. Sí que resulta interessant, d'altra banda, l'ús de la paradoxa igualtat/diferència per a l'anàlisi de la participació femenina: si, per un costat, participar com a iguals en les associacions de veïns acabava invisibilitzant-les, per un altre, la seva presència en espais no mixtes com les Asociaciones de Amas de Casa certament les feia visibles, però a costa de la seva guetització.

Ha estat a partir de recerques doctorals que en els darrers anys s'ha ampliat el coneixement sobre el moviment veïnal a l'Estat espanyol i, especialment, en l'àmbit català. És particularment interessant la tesi de Constantino Gonzalo Morell sobre Valladolid, exemple paradigmàtic de l'extensió i la força d'aquest moviment més enllà de les grans àrees urbanes clàssiques. ${ }^{42}$ La segona aportació, signada per Bordetas, se centra en aquestes - particularment Barcelona, Madrid i Bilbao-; tracta d'establir un model explicatiu sobre la gènesi i evolució d'aquest moviment, i n’arrela els orígens en els processos migratoris i en la configuració suburbial de les ciutats durant la postguerra. De la mateixa manera, aprofundeix en l'estudi de la configuració de xarxes socials als barris i en el procés d'autoorganització veïnal més enllà de considerar com a activadors únics de la protesta a militants de partit i a catòlics de base. ${ }^{43}$ Coincidint, doncs, amb les darreres novetats sobre el tema - això són les tesis de Marc Andreu i de José Miguel Cuesta-, es continua demostrant la importància de la identitat obrera en els discursos i pràctiques veïnals així com el lideratge dels barris obrers en els processos de mobilització social que només a llarg termini esdevenen interclassistes. L'estudi de Marc Andreu, centrat en excés en els lideratges veïnals i en les organitzacions

42 C. Gonzalo Morell, Movimiento vecinal y cultura política democrática en Castilla y León. El caso de Valladolid (1964-1986) (tesi doctoral, Universidad de Valladolid, 2011).

43 I. Bordetas, Nosotros somos los que hemos hecho esta ciudad. Autoorganización y movilización vecinal durante el tardofranquismo y el proceso de cambio político (tesi doctoral, Universitat Autònoma de Barcelona, 2012). 
formals del moviment, particularment en la Federació d'Associacions de Veïns de Barcelona, completa la recerca sobre la protesta urbana a la capital catalana, i en demostra la potencialitat i l'impacte decisius que va assolir, la qual cosa s'exemplifica en la manera que va ser capaç de condicionar l'agenda política de la darrera administració franquista a la Ciutat Comtal. ${ }^{44}$ Per últim, l'estudi de cas de Cuesta — centrat en el Barcelonès Nord-, tot i pecar de massa factual té l'avantatge de prendre com a focus d'estudi la perifèria barcelonina durant una cronologia molt àmplia més enllà de la transició- i d'establir continuïtats i ruptures a partir de l'impacte del model de transició que es va imposar. ${ }^{45}$

Tot i la producció historiogràfica recent, completada amb desenes de petites aportacions en forma d'articles o comunicacions a congressos, estem encara molt lluny de comprendre el fenomen de manera global, rica i complexa. Ni comptem encara amb monografies sobre Madrid o Bilbao, per no parlar d'altres grans àrees urbanes com València o Sevilla, ni tampoc tenim una síntesi general del cas espanyol. Serien també de molt interès els estudis d'història comparada amb casos que, com el portuguès o l'italià, oferirien noves perspectives d'anàlisi sobre uns moviments socials urbans tan potents quantitativament i qualitativa. De la mateixa manera, nous treballs globals, tot i prendre en consideració espais locals, haurien d'implementar la perspectiva de gènere en l'estudi d'un moviment que, com el veïnal, fou espai preferencial per a la participació de les dones. Per últim, resultaria clau, també, adoptar un marc cronològic que superés el temps del canvi polític, tant a l'hora de considerar el primer franquisme com els primers passos del règim democràtic. No tot està per fer, certament; però encara queda molt per investigar.

44 M. ANDREU, El moviment ciutadà i la transició a Barcelona: la FAVB (1972-1986) (tesi doctoral, Universitat de Barcelona, 2014).

45 J.M. Cuesta, El moviment veïnal al Barcelonès Nord (1954-1987) (tesi doctoral, Universitat Autònoma de Barcelona, 2014). 